\title{
Ekstrak Etanol Kayu Secang (Caesalpinia sappan L.) Secara Topikal Efektif pada Kepadatan Kolagen Masa Penyembuhan Luka Insisi Tikus Putih
}

\section{Secang Wood Ethanol Extract (Caesalpinia sappan L.) Topically Effective on Collagen Density During Wound Healing in Albino Rats}

\section{Ricky Eka Sucita ${ }^{1 *}$, Iwan Sahrial Hamid ${ }^{2}$, Faisal Fikri², Muhammad Thohawi Elziyad Purnama $^{3}$}

${ }^{1}$ Pendidikan Profesi Dokter Hewan, ${ }^{2}$ Departemen Ilmu Kedokteran Dasar Veteriner, ${ }^{3}$ Departemen Anatomi Veteriner,

Fakultas Kedokteran Hewan, Universitas Airlangga,

Kampus C UNAIR Mulyorejo, Surabaya, Jawa Timur, Indonesia 60115

Telp. (031)5993016, Fax. (031)5993015

*Corresponding author: rickyres25@gmail.com

\begin{abstract}
Abstrak
Tujuan penelitian ini untuk mengetahui efektivitas ekstrak etanol kayu secang (Caesalpinia sappan L.) secara topikal dapat mempercepat kepadatan kolagen pada penyembuhan luka insisi tikus putih (Rattus norvegicus). Sebanyak 20 ekor tikus jantan dibagi secara acak menjadi lima kelompok, yakni: kontrol negatif (K-) yang diberi basis salep, kontrol positif $(\mathrm{K}+)$ yang diberi salep povidone iodine $10 \%$, kelompok perlakuan (P1; P2; P3) yang diberi salep ekstrak kayu secang 6.5\%; 15\%; 30\%. Perlakuan diberikan pada daerah luka secara topikal sekali sehari selama 14 hari. Data hasil skoring histopatologi diuji dengan uji Kruskal-Wallis dan Mann-Whitney. Kepadatan kolagen luka insisi kelompok P1 berbeda signifikan dengan kelompok P2, P3, K-, dan $\mathrm{K}+$, dan tidak ada kelompok yang berbeda secara signifikan selain itu. Dapat disimpulkan bahwa peningkatan rata-rata kepadatan kolagen pada kelompok P1 adalah dosis optimal.
\end{abstract}

Kata kunci: Caesalpinia sappan L., kayu secang, kepadatan kolagen, penyembuhan luka

\section{Abstract}

This study aimed to determine the effectiveness of Secang wood (Caesalpinia sappan L.) extract topically can increase the density of collagen on incision wound healing in albino rats (Rattus norvegicus). A total of 20 male rats were randomly devided into five groups, i.e., negative control $(K-)$ treated with ointment base, positive control $(K+)$ treated with povidone iodine $10 \%$ ointment, treated groups $(P 1 ; P 2 ; P 3)$ treated with Secang wood extract ointment 6.5\%; 15\%; 30\%. Treatment had been given directly on the subcutan incision area topically once a day for fourteen days. The result data of histopatological appereance were analyzed with Kruskal-Wallis and Mann-Whitney. The collagen density of incision wound on group P1 significantly different with group $P 2, P 3, K$-, and $K+$, and there were no more significantly different groups. It can be concluded that increasing mean of collagen density on Secang wood extract ointment group P1 which indicates that is the optimum dose.

Key words: Caesalpinia sappan L., secang wood, collagen density, wound healing

Received: 5 Mei 2019

Revised: 19 Juni 2019

Accepted: 17 Juli 2019

\section{PENDAHULUAN}

Luka merupakan salah satu kelainan pada kulit dengan terjadinya kerusakan kesatuan atau komponen pada jaringan (Parampasi \& Soemarno, 2013). Luka dapat terjadi secara tidak sengaja, seperti terjatuh, tersayat, tercakar, dan ada yang dilakukan secara sengaja untuk tujuan tertentu, contohnya seperti luka insisi untuk keperluan operasi. Luka pada umumnya menyebabkan rasa sakit, pendarahan, kecacatan 
dan sering memiliki masalah dalam praktik klinis (Nirmal et al., 2014).

Proses penyembuhan luka adalah proses kompleks yang terdiri dari beberapa fase yang terjadi secara berhubungan satu sama lain, yaitu fase inflamasi, fase proliferasi, dan fase remodeling (Wang et al., 2017). Kolagen adalah komponen kunci penyembuhan luka. Paparan kolagen fibriler ke darah akan segera keluar menyebabkan agregasi dan aktivasi trombosit sehingga dapat melepaskan faktor-faktor kemotaksis yang memulai proses penyembuhan luka (Triyono, 2005). Kolagen mempunyai kemampuan homeostasis, interaksi dengan trombosit dan fibronektin dalam proses penyembuhan luka. Kolagen juga dapat meningkatkan eksudasi cairan, meningkatkan komponen seluler, faktor pertumbuhan dan mendorong proses fibroplasia (Novriansyah, 2008).

Pengobatan yang paling banyak digunakan untuk proses penyembuhan luka, salah satunya adalah povidone iodine $10 \%$. Povidone iodine memiliki efek anti mikroba dan dapat menginduksi angiogenesis. Obat ini juga dapat mencegah inflamasi (Putri dkk., 2014). Pemberian povidone iodine untuk penyembuhan luka masih menjadi perdebatan karena menimbulkan efek toksik pada penelitian in vitro tingkat sel (Purnasari dkk., 2012).

Poividone iodine juga memiliki efek negatif, yaitu dapat menghambat pertumbuhan fibroblast. Proses penyembuhan luka sangat dipengaruhi oleh peranan migrasi dan proliferasi fibroblas pada area perlukaan. Proliferasi dari fibroblas menentukan hasil akhir dari penyembuhan luka. Fibroblas akan menghasilkan kolagen yang akan menautkan luka, dan fibroblas juga mempengaruhi proses reepitelisasi yang akan menutup luka. Pertumbuhan fibroblas yang terhambat dapat mengakibatkan potensi penyembuhan luka juga dapat terhambat (Sumbayak, 2016). Pengobatan alternatif lain, seperti pengobatan herbal menjadi salah satu alternatif, karena sifatnya yang terjangkau, baik harga maupun tingkat keamanannya.

Indonesia merupakan negara beriklim tropis yang memiliki sumber daya alam yang sangat melimpah, salah satu potensi alamnya yang bisa dimanfaatkan yaitu tanaman kayu secang (Caesalpinia sappan L.). Tanaman ini termasuk dalam famili Leguminosae yang pada umumnya lebih dikenal sebagai kayu Brazil atau Sappan. Nirmal et al., (2015) menyebutkan kayu secang memiliki berbagai manfaat biologis, seperti antiinflamasi, antibakteri, aktivitas antioksidan, antialergi, aktivitas nuklease, analgesik, dan lain sebagainya.

Kusmiati, dkk (2014) menyebutkan bahwa senyawa aktif pada kayu secang terdapat flavonoid, saponin, alkaloid, tanin, fenolik, dan brazilin. Kandungan saponin, flavonoid, dan alkaloid yang berfungsi sebagai antioksidan, antiinflamasi, dan bersifat antifungi, serta tanin yang dapat menunjukkan aktifitas antivirus, dan antibakteri. Senyawa spesifik yang terdapat dalam kandungan kayu secang adalah brazilin, yang mempunyai efek anti inflamasi (Winarti dan Nurdjanah, 2005). Senyawa-senyawa aktif tersebut berpotensi dapat bermanfaat dalam proses penyembuhan luka.

\section{METODE PENELITIAN}

Penelitian menggunakan metode Rancangan Acak Lengkap (RAL) dan merupakan penelitian eksperimental menggunakan tikus putih (Rattus norvegicus) sebanyak 20 ekor dibagi dalam lima kelompok perlakuan. Objek yang diteliti adalah kulit hewan coba yang telah diberikan luka insisi lalu diberi pengobatan dengan ekstrak kayu secang selama 14 hari.

Kayu secang yang diperoleh, diserut terlebih dahulu, lalu dikeringkan di bawah sinar matahari langsung selama dua hari. Kayu secang yang sudah kering dihaluskan dengan blender serta diayak dengan saringan berdiameter 80 mesh. Hasil berupa serbuk kayu secang kemudian disimpan dalam wadah tertutup rapat. Hasil tersebut lalu akan dilanjutkan dengan proses ekstraksi kayu secang dengan cara direndam di larutan etanol 95\% dalam kondisi refluks selama 3 hari pada suhu normal. Proses penyaringan dilakukan setelah proses perendaman. Ekstraksi diulang kembali hingga hasilnya sempurna. Filtrat yang terbentuk kemudian disaring dengan 
kertas saring dan dilakukan sebanyak dua kali, untuk memisahkan brazilin dengan pelarutnya. Filtrat kemudian diuapkan sampai kering di bawah konsentrator dengan tekanan yang terus berkurang selama 3 jam. Hasil filtrat ekstrak etanol kemudian di pekatkan dengan alat rotary evaporator sampai hasil yang didapat berupa ekstrak kental.

Tikus jantan dibius terlebih dulu menggunakan kombinasi Ketamine 50mg/kgBB dan Xylazine 5mg/kgBB (Suckow et al., 2006) secara intramuscular sebelum diberikan luka insisi. Langkah selanjutnya mengeksisi kulit tikus putih pada area yang telah diinsisi seluas $3 \times 3 \mathrm{~cm}^{2}$. Jaringan yang diambil difiksasi dalam larutan buffer formalin $10 \%$ yang selanjutnya dibuat sediaan preparat histopatologi.

Konsentrasi yang akan digunakan dalam penelitian ini yaitu $6.5 \%, 15 \%$, dan $30 \%$ telah diteliti oleh Tewtrakul et al. (2015) secara in vitro sebagai penyembuhan luka. Konsentrasi ekstrak kayu secang dilarutkan dalam vehikulum unguentum. Kepadatan kolagen diinterpretasikan secara semikuantitatif menggunakan skoring histopatologi untuk kepadatan kolagen berdasarkan perhitungan 4 lapang pandang, pada obyek pembesaran 400 kali.

Menurut Rizka dan Budipramana, (2013), metode skoring, yakni: (0) Tidak ditemukan adanya serabut kolagen pada daerah luka; (1) Kepadatan serabut kolagen pada daerah luka rendah (<10\%); (2) Kepadatan kolagen pada daerah luka sedang (10\%-50\%); (3) Kepadatan serabut kolagen pada daerah luka rapat $(50 \%$ 90\%); (4) Kepadatan kolagen pada daerah luka sangat rapat $(90 \%-100 \%)$.

Data skor kepadatan kolagen dianalisis menggunakan uji Kruskal-Wallis dilanjutkan dengan uji Mann-Whitney- $U$ apabila terdapat perbedaan nyata dengan derajat kemaknaan $\mathrm{p}<0.05$.

\section{HASIL DAN PEMBAHASAN}

Data skoring dengan Kruskal-Wallis hasil $\mathrm{p}=0.044$ yang menunjukkan terdapat perbedaan yang nyata pada kelompok perlakuan $(\mathrm{p}<0.05)$. Perbedaan setiap kelompok perlakuan dilanjutkan dengan uji beda Mann-Whitney yang menghasilkan $\mathrm{P} 1$ berbeda nyata $(\mathrm{p}<0.05)$ dengan $\mathrm{K}-$, K+, P2, dan P3. Kelompok perlakuan K-, $\mathrm{K}+$, $\mathrm{P} 2$, dan $\mathrm{P} 3$ tidak terdapat perbedaan nyata $(\mathrm{p}<0.05)$ (Tabel 1).

Kelompok perlakuan K- (basis salep) daerah luka insisi sudah menutup, jaringan kolagen sudah terbentuk, dan terdapat beberapa infiltrasi sel radang, serta dengan rata-rata kepadatan kolagen lebih rendah dari kelompok lainnya 1.87 (Tabel 1).

Kelompok perlakuan $\mathrm{K}+$ (povidone iodine $10 \%$ ) daerah luka insisi sudah menutup, jaringan kolagen terbentuk lebih padat dari kontrol negatif, dan terdapat lebih sedikit infiltrasi sel radang, dengan rata-rata kepadatan kolagen 2.12 (Tabel 1).

Gambaran histopatologi kelompok P1 (ekstrak kayu secang 6.5\%) pada daerah luka insisi menutup, jaringan kolagen terbentuk lebih tebal dan padat dari kelompok perlakuan lainnya, dengan rata-rata kepadatan kolagen 3.18 (Tabel $1)$.

Gambaran histopatologi kelompok P2 (ekstrak kayu secang 15\%) pada daerah luka insisi sudah menutup, jaringan kolagen sudah terbentuk lebih jarang dan tipis dari kelompok perlakuan P1 namun lebih padat dari kelompok perlakuan lainnya, dan terdapat sel radang lebih sedikit dari kontrol positif, dengan rata-rata kepadatan kolagen 2.43 (Tabel 1).

Gambaran histopatologi kelompok P3 (ekstrak kayu secang 30\%) pada daerah luka insisi sudah menutup, jaringan kolagen sudah terbentuk lebih jarang dari kelompok perlakuan P1 dan P2, dan terdapat sel radang, dengan ratarata kepadatan kolagen 2.12 (Tabel 1).

Kepadatan kolagen pada kelompok perlakuan K- (basis salep) pada penelitian ini memiliki skor yang paling rendah diantara semua kelompok perlakuan lainnya. Hasil tersebut dapat terjadi karena pada kelompok perlakuan K- (basis salep) merupakan kelompok perlakuan tikus putih yang diberi luka insisi tanpa diberikan zat atau bahan obat yang berkhasiat untuk membantu proses penyembuhan luka sehingga masa inflamasi menjadi lebih lama yang mengakibatkan 
Tabel 1. Rata-rata dan standard deviasi kepadatan kolagen kulit tikus putih setiap perlakuan

\begin{tabular}{lr}
\hline \multicolumn{1}{c}{ Perlakuan } & Rata-rata kepadatan kola \\
\hline K- (basis salep) & $1.87^{\mathrm{a}} \pm 0.63$ \\
K+ (povidone iodine 10\%) & $2.12^{\mathrm{a}} \pm 0.63$ \\
P1 (ekstrak kayu secang 6.5\%) & $3.18^{\mathrm{b}} \pm 0.24$ \\
P2 (ekstrak kayu secang 15\%) & $2.43^{\mathrm{a}} \pm 0.42$ \\
P3 (ekstrak kayu secang 30\%) & $2.12^{\mathrm{a}} \pm 0.48$ \\
\hline
\end{tabular}

Superskrip berbeda pada kolom yang sama menunjukkan hasil yang berbeda nyata $(\mathrm{p}<0.05)$

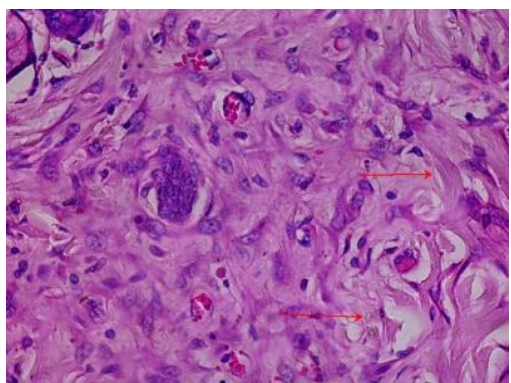

K-

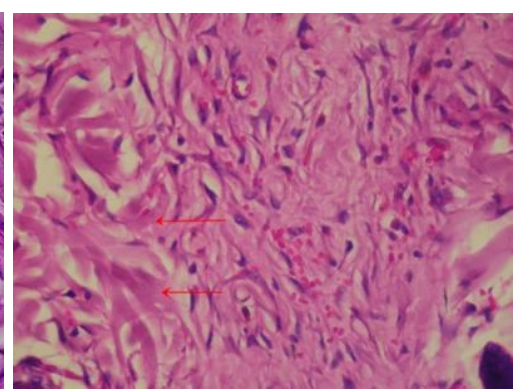

$\mathrm{K}+$

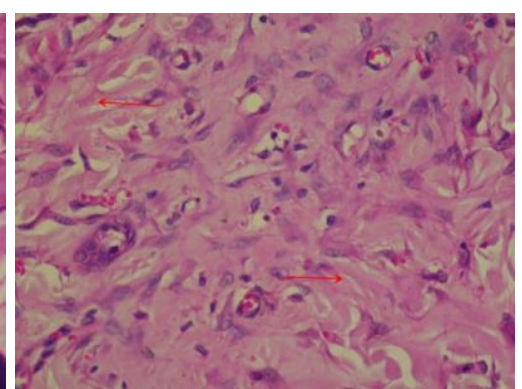

P1

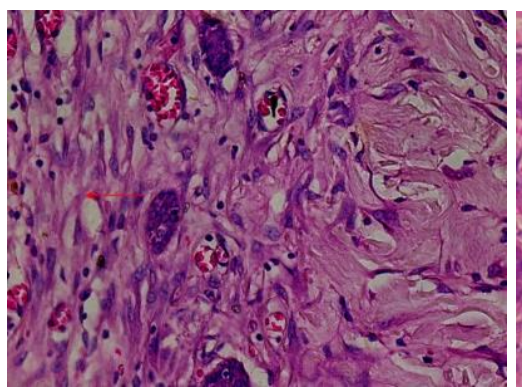

$\mathrm{P} 2$

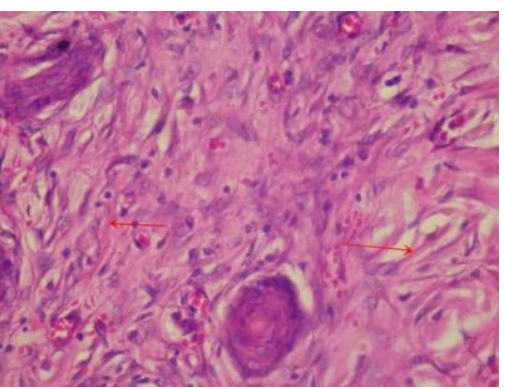

P3

Gambar 1. Kepadatan kolagen $(\rightarrow)$ pada setiap perlakuan

penyembuhan luka tidak bekerja secepat semestinya, bahkan terganggu (Pongsipulung, 2012) dan menyebabkan stimulasi kolagen rendah (Novriansyah, 2012).

Kepadatan kolagen pada kelompok perlakuan $\mathrm{K}+$ (povidone iodine 10\%) pada penelitian ini memiliki skor yang lebih tinggi dibandingkan dengan kelompok perlakuan $\mathrm{K}$ (basis salep) dan skor sama dengan kelompok perlakuan P3 (ekstrak kayu secang 30\%) (Gambar 1). Hasil ini terjadi karena pada kelompok perlakuan $\mathrm{K}+$ (povidone iodine 10\%) diberi salep povidone iodine $10 \%$ (Betadine $^{\circledR}$ ) yang merupakan senyawa zat anti bakteri yang secara umum dapat digunakan untuk membantu proses penyembuhan luka dalam mencegah terjadinya kontaminasi mikroba dengan menghambat pembentukan protein pada mikroba sehingga mikroba tersebut tidak dapat berkembang pada jaringan yang mengalami luka
(Rahmawati, 2014). Obat ini juga dapat meningkatkan kepadatan kolagen dengan mencegah inflamasi berlebih dan fase inflamasi dapat terlewati lebih cepat pada proses penyembuhan luka (Nurdiantini dkk., 2017).

Kepadatan kolagen pada kelompok perlakuan P1 (ekstrak kayu secang 6.5\%) memiliki skor yang paling tinggi dan paling berbeda nyata diantara kelompok perlakuan yang lainnya. Penelitian ini membuktikan bahwa salep ekstrak kayu secang dengan konsentrasi 6.5\% merupakan dosis yang optimum. Hasil ini berkaitan dengan mengenai adanya kandungan metabolit sekunder tanaman secang yang berkhasiat sebagai obat. Zat metabolit yang ada di dalam tanaman, khususnya kayu secang antara lain, flavonoid, saponin, tanin, dan alkaloid, dan senyawa spesifik pada kayu secang, yaitu brazilin (Kusmiati dkk., 2014). 
Saponin berperan meningkatkan permeabilitas membran yang menyebabkan terjadinya hemolisis sel, apabila saponin berinteraksi dengan sel bakteri, makan bakteri tersebut dapat akan lisis. Proliferasi monosit dapat ditingkatkan oleh saponin dan mengakibatkan meningkatnya jumlah makrofag dan mensekresi growth factor dalam menghasilkan fibroblas dan mensintesis kolagen ke daerah luka. Saponin juga dapat mempercepat proses migrasi keratinosit yang berperan penting dalam proses re-epitelisasi (Ardiana dkk., 2015). Flavonoid mempunyai kemampuan sebagai antioksidan yang mampu mengurangi radikal bebas. Radikal bebas dapat menghambat terjadinya proliferasi sel, menghambat reaksi inflamasi, serta menghambat kontraksi dari jaringan kolagen yang terbentuk, sehingga menyebabkan terhambatnya proses penyembuhan luka (Paju, 2013).

Senyawa spesifik pada kayu secang yaitu, brazilin mempunyai efek anti inflamasi dan anti bakteri (Winarti dan Nurdjanah, 2005). Brazilin pada kayu secang memiliki daya antioksidan yang lebih tinggi daripada antioksidan komersial (BHT dan BHA) sehingga lebih potensial sebagai penangkal radikal bebas (Farhana dkk., 2015). Antioksidan jika berikatan dengan radikal bebas, maka kerusakan membran sel dapat berkurang, sehingga fase proliferasi dapat berjalan (Ardiana dkk., 2015). Peran senyawa fenolik yang terkandung dalam kayu secang, juga membantu flavonoid dan brazilin dalam mencegah reaksi oksidasi dengan cara menghentikan reaksi berantai akibat timbulnya radikal bebas. Senyawa fenolik berperan sebagai donor hidrogen yang dapat mencegah pembentukan radikal bebas (Yemirta, 2010).

Kandungan tanin dalam ekstrak kayu secang dapat mempercepat penyembuhan luka dengan beberapa mekanisme seluler yaitu membersihkan radikal bebas dan oksigen reaktif, meningkatkan penyambungan luka serta meningkatkan pembentukan pembuluh darah kapiler dan fibroblas (Kusumawardhani dkk., 2015; Hamid et al., 2018). Tanin berfungsi sebagai astringen yang dapat menghentikan eksudat dan perdarahan ringan sehingga mampu mempercepat menutupnya luka. Tanin dan saponin berperan dalam migrasi dan proliferasi fibroblast pada daerah luka (Izzati, 2015).

Faktor-faktor yang dapat membedakan dan mempegaruhi hasilnya selain itu, adalah kelembaban. Kelembaban merupakan sifat permeabel bagi oksigen dan uap air serta bersifat oklusif terhadap bakteri dan air sehingga penyembuhan luka tidak terganggu. Oksigen merupakan nutrisi yang penting bagi metabolisme sel. Oksigenasi merupakan salah satu faktor penting yang mempengaruhi proses penyembuhan luka (Arisanty, 2013). Kelompok perlakuan P1 (ekstrak kayu secang 6.5\%) memiliki kadar kelembaban lebih tinggi diantara P2 (ekstrak kayu secang 15\%) dan kelompok P3 (ekstrak kayu secang 30\%). Kadar kelembaban yang cukup tinggi mampu menyebabkan oksigen dalam jaringan luka juga tinggi, sehingga proses proliferasi fibroblas dapat meningkat dan akan menstimulasi pembentukan kolagen lebih cepat (Novriansyah, 2008).

Kepadatan kolagen pada kelompok perlakuan P2 (ekstrak kayu secang 15\%) memiliki skor yang sedikit lebih tinggi dari kelompok perlakuan $\mathrm{K}+$ (povidone iodine 10\%) dan K- (basis salep), namun peningkatannya tidak terlalu signifikan. Kelompok perlakuan P3 (ekstrak kayu secang 30\%) memiliki skor yang sama dengan kelompok perlakuan $\mathrm{K}+$ (povidone iodine 10\%) dan sedikit lebih tinggi dari kelompok perlakuan K- (basis salep). Hasil ini menggambarkan bahwa salep ekstrak kayu secang dengan konsentrasi $15 \%$ dan konsentrasi $30 \%$ dapat memberikan efek penyembuhan luka lebih cepat dan dapat membantu meningkatkan kepadatan kolagen, namun tidak semaksimal kelompok perlakuan P1 (ekstrak kayu secang 6.5\%). Hasil tersebut dipengaruhi oleh oksigenasi dan kadar kelembaban yang merupakan salah satu faktor penting yang mempengaruhi proses penyembuhan luka (Arisanty, 2013; Purnama et al., 2019).

Hasil kelompok perlakuan P2 (ekstrak kayu secang 15\%) dan kelompok perlakuan P3 (ekstrak kayu secang 30\%) memiliki kadar kelembaban lebih rendah dari kelompok perlakuan P1 (ekstrak kayu secang 6.5\%). 
Kelembaban yang rendah akan mengakibatkan tekanan oksigen dalam jaringan luka menurun sehingga mempengaruhi fungsi neutrofil, makrofag, dan fibroblas, sehingga dapat menyebabkan proses sintesis kolagen akan sedikit terhambat (Novriansyah, 2008). Kadar flavonoid juga menjadi faktor yang mempengaruhi, karena mengalami penurunan pada konsentrasi ekstrak yang tinggi. Penurunan tersebut disebabkan oleh peningkatan kepekatan dari larutan ekstrak yang mengakibatkan penurunan aktivitas antioksidannya (Nijveldt et al., 2001). Tingkat kepekatan larutan yang tinggi dapat menghambat zat senyawa saponin untuk menembus mukosa membran (Indraswary, 2014)

\section{KESIMPULAN}

Pemberian ekstrak kayu secang (Caesalpinia sappan L.) dengan konsentrasi $6.5 \%$ secara topikal selama 14 hari dapat meningkatkan kepadatan kolagen dalam proses penyembuhan luka insisi pada tikus putih.

\section{UCAPAN TERIMA KASIH}

Penulis mengucapkan terimakasih kepada Universitas Airlangga PSDKU Banyuwangi atas dukungan fasilitas sehingga penelitian ini dapat dilaksanakan.

\section{DAFTAR PUSTAKA}

Ardiana, T., Kusuma, A.R.P., Firdausy. 2015. Efektivitas Pemberian Gel Binahong (Anredera cordifolia) 5\% Terhadap Jumlah Sel Fibroblas Pada Soket Pasca Pencabutan Gigi Marmut (Carvia cobaya). [Skripsi]. Fakultas Kedokteran Gigi. Universitas Islam Sultan Agung. Semarang.

Arisanty, I.P. 2013. Manajemen Perawatan

Luka. Penerbit Buku Kedokteran EGC.

Farhana, H., Maulana, I.T., Kodir, R.A. 2015. Perbandingan Pengaruh Suhu dan Waktu Perebusan Terhadap Kandungan Brazilin pada Kayu Secang (Caesalpinia sappan L.). Prosiding Penelitian SPeSIA Unisba.

Hamid, I.S., Aksono, E.B., Sukmanadi, M., Purnama, M.T.E. 2018. Antiangiogenesis activity test of tin leaf (Ficus carica L.) on the number of blood vessels and VEGF expression of chorioallantoic membrane of embryonated chicken eggs. Eur. J. Oncol. Pharm., 1(4), e00007.

Indraswary, R. 2014. Efek Konsentrasi Ekstrak Buah Adas (Foeniculum vulgare Mill.) Topikal Pada Epitelisasi Penyembuhan Luka Gingiva Labial Tikus Sprague Dawley In Vivo. [Skripsi]. Fakultas Kedokteran Gigi. Universitas Islam Sultan Agung. Semarang.

Izzati, U.Z. 2015. Efektivitas Penyembuhan Luka Bakar Salep Ekstrak Etanol Daun Senggani (Melastoma malabathricum L.) pada Tikus Putih (Rattus norvegicus) Jantan Galur Wistar. [Skripsi]. Universitas Tanjungpura. Pontianak.

Kusmiati, Dameria, Priadi, D. 2014. Analisa Senyawa Aktif Ekstrak Kayu Secang (Caesalpinia Sappan L.) Yang Berpotensi Sebagai Antimikroba. Pusat Penelitian Bioteknologi. Jakarta.

Kusumawardhani, A.D., Kalsum, U., Rini, I.S. 2015. Pengaruh Sediaan Salep Ekstrak Daun Sirih (Piper betle Linn.) terhadap Jumlah Fibroblas Luka Bakar Derajat IIA pada Tikus Putih (Rattus norvegicus) Galur Wistar. Majalah Kesehatan FKUB. Malang.

Nijveldt, R.J., Van, N.E., Van, H.E., Boelens, P.G., Van, N.K., Van, L. 2001. Flavonoids: A Review Of Probable Mechanisms Of Action And Potential Application. Am. J. Clinn. Nutr., 74(4), 418-425.

Nirmal, N.P., Prasad, R.G.S.V., Keokitichai, S. 2014. Wound healing activity of standardized brazilin rich extract from 
Caesalpinia sappan heartwood. J. Chem. Pharm. Res., 6(10), 195-201.

Nirmal, N.P., Rajput, M.S., Prasad, R.G.S.V., Ahmad, M. 2015. Brazilin from Caesalpinia sappan heartwood and its pharmacological activities: A review. As. Pacific J. Trop. Med., (6): 421-430.

Novriansyah, R. 2008. Perbedaan Kepadatan Kolagen disekitar Luka Insisi Tikus Wistar yang Dibalut Kasa Konvensional dan Penutup Oklusif Hidrokoloid selama 2 dan 14 Hari. Ilmu Bedah Univeritas Diponegoro. Semarang. p7-19.

Nurdiantini, I., Prastiwi, S., Nurmaningsari, T. 2017. Perbedaan Efek Penggunaan Povidone Iodine $10 \%$ Dengan Minyak Zaitun Terhadap Penyembuhan Luka Robek (Lacerated Wound). Keperawatan Poltekkes Kemenkes. Malang. 2(1).

Paju, N. 2013. Uji Efektivitas Salep Ekstrak Daun Binahong (Anredera cordifolia) pada Kelinci (Oryctolagus cuniculus) yang Terinfeksi Bakteri Staphylococcus aureus. J. Ilmiah Farmasi UNSRAT, 2(1), 53.

Parampasi, N., Soemarno, T. 2013. Pengaruh Pemberian Ekstrak Daun Pepaya dalam Etanol 70\% pada Proses Penyembuhan Luka Insisi. Departemen Patologi Anatomik, Fakultas Kedokteran Universitas Airlangga. Surabaya.

Pongsipulung, R.G. 2012. Formulasi dan Pengujian Salep Ekstrak Bonggol Pisang Ambon (Musa paradisiacal var. saoientum L.) terhadap Luka Terbuka pada Kulit Tikus Putih Jantan Galur Wistar (Rattus norvegicus). 1(2).

Purnama, M.T.E., Rahmaningtyas, I.H., Pratama, A.R., Prastika, Z., Kartikasari, A.M., Cahyo, N.P.D. 2019. Tadpole serum activity (Rana catesbeiana) in caspase- 3 as a marker of the role of apoptosis and total cytotoxic $\mathrm{T}$ lymphocytes in albino rats' epithelial cells induced by neoplasia. Vet. World, 12(1), 6367.

Purnasari, P.W., Fatmawati, D., Yusuf, I. 2012. Pengaruh Lendir Bekicot (Achatina fulica) terhadap Jumlah Sel Fibroblas pada Penyembuhan Luka Sayat. Bagian Biologi Fakultas Kedokteran Universitas Islam Sultan Agung, 4(2).

Putri, S.A., Sutadipura, N., Roekmantara, T. 2014. Efek Ekstrak Etanol Daun Cocor Bebek (Kalanchoe pinnata [Lam] Pers.) terhadap Waktu Penyembuhan Luka Sayat pada Tikus putih Jantan Galur Wistar. Fakultas Kedokteran: Universitas Islam Bandung. p886-887.

Rahmawati, I. 2014. Perbedaan Efek Perawatan Luka Menggunakan Gerusan Daun Petai Cina (Leucaena glauca, Benth) dan Povidone Iodine $10 \%$ dalam Mempercepat Penyembuhan Luka Bersih pada Marmut (Cavia porcellus). J. Wiyata. 1(2), 227-234.

Rizka, A., Budipramana, V.S. 2013. Kepadatan Kolagen tipe 1 pada luka operasi tikus Wistar yang mengalami anemia karena perdarahan akut. Media J. Emerg., 2(1), 1.

Suckow, M.A., Weisbroth, S.H., Franklin, C.L. 2006. The Laboratory Rat. American College of Laboratory. Elsevier Academic Press. USA. p655.

Sumbayak, E.M. 2016. Fibroblas: Struktur dan Peranannya dalam Penyembuhan Luka. Histologi FK UKRIDA. Jakarta.

Tewtrakul, S., Tungcharoen, P., Sudsai, T., Karalai, C., Ponglimanont, C., Yodsaoue, O. 2015. Antiinflammatory and Wound Healing Effects of Caesalpinia sappan $L$. Phytotherapy Res., 29(6).

Triyono, B. 2005. Perbedaan Tampilan Kolagen Di Sekitar Luka Insisi Pada Tikus Wistar 
Yang Diberi Infiltrasi Penghilang Nyeri Levobupivakain Dan Yang Tidak Diberi Levobupivakain. Universitas Diponegoro. Semarang.

Wang, P.H., Huang, B.S., Horng, H.C., Yeh, C.C., Chen, Y.J. 2017. Wound healing. J. Chin. Med. Assoc., 81(2018), 94-101.

Winarti, C., Nurdjanah, N. 2005, Peluang Tanaman Rempah dan Obat Sebagai Sumber
Pangan Fungsional, J. Litbang Pertanian, 24(2), 47-55.

Yemirta. 2010. Identifikasi Kandungan Senyawa Antioksidan Dalam Kayu Secang (Caesalpinia Sappan L.). Balai Besar Kimia dan Kemasan, Kementerian Perindustrian RI. Jakarta Timur. J. Kimia dan Kemasan, 32(2), 41-46. 